\title{
PENGARUH PENDIDIKAN KESEHATAN DENGAN METODE ROLE PLAY TERHADAP PENGETAHUAN DAN SIKAP SISWA KELAS X
}

\author{
Farid Setyo Nugroho 1 \\ ${ }^{1}$ Program Studi Kesehatan Masyarakat Fakultas Kesehatan Masyarakat, \\ Universitas Veteran Bangun Nusantara Sukoharjo, Jl. Letjend Sujono Humardani \\ No. 1 Sukoharjo \\ Email : faridsetyo25@gmail.com
}

\begin{abstract}
ABSTRAK
Masih tingginya stigma dan diskriminasi terhadap Orang Dengan HIV dan AIDS (ODHA) dan Anak Dengan HIV dan AIDS (ADHA) disebabkan kurangnya pengetahuan dan sikap masyarakat tentang tata cara penularan HIV. Tujuan dalam penelitian ini adalah untuk mengetahui pengaruh pendidikan kesehatan dengan metode roleplay tentang ODHA terhadap pengetahuan dan sikap siswa kelas $\mathrm{X}$. Penelitian ini menggunakan quasi eksperimen dengan Pre dan Post Test.Terdapat pengaruh pendidikan kesehatan dengan metode role play dengan pengetahuan siswa kelas $\mathrm{X}$ tentang ODHA dimana $p$ value sebesar 0,000 . Terdapat pengaruh pendidikan kesehatan dengan metode roleplay dengan sikap siswa kelas $\mathrm{X}$ tentang ODHA dimana $p$ value sebesar 0,000 . Pendidikan kesehatan dengan role play memberikan pengaruh terhadap peningkatan pengetahuan dan terbentuknya sikap yang positif terhadap ODHA.
\end{abstract}

Kata kunci : AIDS, HIV, Pendidikan kesehatan, Roleplay, Siswa

\begin{abstract}
The stigma and discrimination against people lived with HIV and AIDS and Children with HIV and AIDS was high due to a lacked of community knowledge and attitudes about HIV transmission procedures. The purposed of this study was to determine the effect of health education with roleplay methods about people lived with HIV and AIDS on students' knowledge and attitudes. This study used a quasi-experimental method with Pre and Post Test. There was influence of health education using the role play method with class X students' knowledge about people lived with HIV and AIDS where the $\mathrm{p}$ value $=0,000$. There was influence of health education with roleplay methods with the attitude of class $\mathrm{X}$ students about people lived with HIV and AIDS where the $\mathrm{p}$ value $=0,000$. Health education with role play had an effect on increased knowledge and forming positive attitudes towards people lived with HIV and AIDS.
\end{abstract}

Keywords: AIDS, HIV, Helath education, Roleplay, Students 


\section{PENDAHULUAN}

Human Immunodeficiency Virus atau HIV adalah virus golongan RNA yang spesifik menyerang sistem kekebalan tubuh manusia dan menyebabkan AIDS. AIDS merupakan kependekan dari Acquired Immune Deficiency Syndrome. Acquired" artinya didapat bukan diturunkan ; "Immune" adalah sistem daya tahan atau kekebalan tubuh; "Deficiency" artinya tidak cukup atau kurang; dan "Syndrome" adalah kumpulan tanda dan gejala penyakit (Card et al., 2008; Vorberding, Sande, Lange dan Greene, 2008).

Orang Dengan HIV dan AIDS (ODHA) dan Anak Dengan HIV dan AIDS (ADHA) merupakan istilah yang merujuk kepada seseorang yang secara laboratoris dinyatakan positif terinfeksi Human Immunodeficiency Virus (HIV). Stigma dan diskriminasi sering dialami oleh populasi ini, baik berupa dikucilkan di masyarakat dan hambatan dalam mendapatkan akses layanan kesehatan serta tidak diperkenankan mengikuti sekolah (KPA, 2009). Oleh sebab itu, diperlukan adanya sebuah upaya untuk menghilangkan stigma dan diskriminasi serta mendukung upaya pencegahan dan perawatan serta pengobatan secara maksimal bagi populasi ini (Kementrian Kesehatan, 2011)

Jumlah penderita HIV sampai pada bulan Juni tahun 2018 sebesar 301.959 penderita (47\% dari perkiraan yang terinfeksi jumlah orang dengan HIV dan AIDS pada tahun 2018 sebesar 640.443 penderita) penderita HIV dan AIDS paling banyak ditemukan pada kelompok usia 25-49 tahun dan 20-24 tahun. Provinsi dengan penderita HIV paling tinggi di
Indonesia yaitu DKI Jakarta sebesar 55.099, selanjutnya Jawa Timur sebesar 43.399, Jawa Barat sebesar 31.293, Papua sebesar 30.699, dan Jawa Tengah sebesar 24.757 (Kemkes RI, 2018).

Berdasarkan hasil Riset Kesehatan Dasar tahun 2018 diketahui bahwa pengetahuan masyarakat yang benar tentang HIV dan AIDS baik dari sisi pengertian, cara penularan dan pencegahan, serta cara pengobatannya masih rendah yaitu sebesar 31,8\% (Kemkes RI, 2018). Pengetahuan yang masih rendah kemungkinan menyebabkan terjadinya stigma dan diskriminasi terhadap ODHA. Undangundang kesehatan tahun 2009 no 36 pasal 7 dan 8 tahun bahwa setiap orang berhak untuk mendapatkan informasi dan edukasi tentang kesehatan yang seimbang dan bertanggung jawab serta memperoleh informasi tentang data kesehatan dirinya termasuk tindakan dan pengobatan yang telah maupun yang akan diterimanya dari tenaga kesehatan (Depkes RI, 2009).

Kabupaten

Sukoharjo merupakan salah satu kabupaten yang berada di Provinsi Jawa Tengah. Berdasarkan data Komisi Penanggulangan AIDS (KPA) Sukoharjo total kasus HIV dan AIDS sampai dengan Desember 2018 adalah 519 kasus. Sebanyak 6\% atau 32 penderita masih tergolong dalam kategori pelajar atau mahasiswa, sedangkan sebanyak $87 \%$ atau 451 penderita masih tergolong dalam usia produktif Hal ini menunjukkan bahwa masih banyaknya ODHA pada kalangan pelajar atau mahasiswa atau pada usia produktif (KPA Kabupaten Sukoharjo, 2018).

Berdasarkan penelitian Hati dkk (2017) pengetahuan, persepsi, dan 
sikap memberikan pengaruh stigma terhadap ODHA. Masih rendahnya pengetahuan masyarakat tentang penularan HIV, sikap masyarakat tentang ODHA serta masih banyak terjadinya stigma serta diskrimimasi terhadap ODHA membuat peneliti tertarik untuk mengetahui apakah pendidikan kesehatan dengan metode role play tentang ODHA dapat meningkatkan pengetahuan dan membentuk sikap yang positif pada remaja?

\section{METODE PENELITIAN}

Jenis Penelitian ini adalah kuantitatif dengan menggunakan rancangan Quasi eksperimen dengan Pre dan Post Test. Populasi dalam penelitian ini adalah siswa di SMAN I Sukoharjo sejumlah 725. Berdasarkan perhitungan menggunakan sampel tunggal untuk estimasi proporsi diperoleh sampel sebesar 61 siswa, sedangkan teknik pengambilan sampel menggunakan teknik simple random sampling. Pendidikan kesehatan tentang tatacara penularan HIV diberikan dengan metode role play yaitu metode yang diberikan dengan cara bermain peran yang diperankan oleh beberapa orang (drama) dan ditampilkan oleh siswa. Langkah penelitiannya antara lain : siswa mengisi pretest dengan menggunakan kuesioner, penampilan roleplay dan siswa mengisi post test menggunakan kuesioner. Data pengetahuan yang diambil yaitu tentang tatacara penularan HIV dan data sikap siswa terhadap ODHA.

Uji Wilcoxon digunakan pada variabel pengetahuan karena distribusi data tidak normal dan uji Paired T-test digunakan pada variabel sikap karena data berdistribusi normal.

\section{HASIL DAN PEMBAHASAN}

\section{Role Play}

Metode bermain peran dalam penelitian ini mengambil cerita tentang seorang anak sekolah yang memiliki banyak pacar, dan melakukan hubungan seks bebas. Siswa ini kemudian menderita penyakit pembengkakan kelenjar getah bening, setelah diperiksa pada puskesmas, ternyata siswa tersebut terinfeksi HIV. Keadaan ini kemudian diketahui oleh teman-teman disekolahnya, yang kemudian mengalami stigma. Selanjutnya Warga Peduli AIDS (WPA) memberikan pendidikan kesehatan mengenai cara penularan HIV, pencegahan, dan pengobatannya. Setelah mendapatkan pendidikan kesehatan, siswa memahami tentang HIV, sehingga tidak lagi menstigma temanya yg terinfeksi HIV.

Reponden dalam penelitian ini adalah siswa kelas $X$, alasan peneliti memilih kelas $X$ sebagai responden karena merupakan siswa yang baru saja memasuki jenjang SMA, dan penelitian ini dilakukan 1 bulan setelah penerimaan siswa baru, sehingga pengetahuan responden mengenai ODHA masih kurang, akan tetapi setelah diberikan pendidikan kesehatan tingkat pengetahuan responden tentang ODHA menjadi meningkat. Menurut Sardiman (2011) menyatakan belajar merupakan perubahan perilaku atau tampilan dengan serangkaian kegiatan seperti meniru, mendengarkan, membaca, mengamati sedangkan menurut Winkel dalam (Purwanto, 2008) mengatakan belajar merupakan kegiatan mental atau psikologis yang 
berinteraksi aktif dengan lingkungan dan menghasilkan perubahanperubahan pengetahuan, keterampilan dan sikap." Terjadinya perubahan diperoleh melalui hasil pengamatan.

\section{Karaktersitik responden}

\section{Jenis kelamin}

Tabel 1 Distribusi frekuensi jenis kelamin responden

\begin{tabular}{ccc}
\hline Jenis & Frekuensi & Persentase (\%) \\
Kelamin & & \\
\hline Laki-laki & 24 & 39,3 \\
Perempuan & 37 & 60,7 \\
Total & 61 & 100 \\
\hline
\end{tabular}

Berdasarkan Tabel 1 diketahui bahwa sebagian besar sebagian besar responden berjenis kelamin perempuan dengan jumlah 37 responden $(60,7 \%)$. Responden merupakan Siswa kelas X di SMAN I Sukoharjo yang berada pada tingkat kelas yang sama, maka untuk mengetahui karakteristik responden peneliti memberikan pertanyaan mengenai jenis kelamin dan usia responden. Sebagian besar responden berjenis kelamin perempuan sebesar 37 responden. Responden merupakan Siswa kelas X di SMAN I Sukoharjo yang berada pada tingkat kelas yang sama, maka untuk mengetahui karakteristik responden peneliti memberikan pertanyaan mengenai jenis kelamin dan usia responden. Sebagian besar responden berjenis kelamin perempuan sebesar 37 responden.

Responden merupakan siswa yang baru saja memasuki jenjang SMA, karena penelitian ini dilakukan 1 bulan setelah penerimaan siswa baru, sehingga pengetahuan responden mengenai ODHA masih kurang, akan tetapi setelah diberikan pendidikan kesehatan tingkat pengetahuan responden tentang ODHA menjadi meningkat. Begitu pula dengan sikap responden tentang ODHA, sebelum diberikan pendidikan kesehatan responden masih memiliki sikap yang negatif yaitu enggan untuk berjabat tangan dan berpelukan dengan ODHA karena takut tertular HIV, setelah diberikan pendidikan kesehatan, responden menunjukkan sikap yang positif yaitu bersedia berjabat tangan dan berpelukan dengan ODHA.

\section{Usia}

Tabel 2 Distribusi frekuensi usia responden

\begin{tabular}{lcc}
\hline \multicolumn{1}{c}{ Umur } & Frekuensi & $\begin{array}{c}\text { Persentase } \\
(\%)\end{array}$ \\
\hline 15 tahun & 5 & 8,2 \\
16 tahun & 46 & 75,4 \\
17 tahun & 10 & 16,4 \\
Total & 61 & 100 \\
\hline
\end{tabular}

Berdasarkan Tabel 2 diketahui bahwa sebagian besar responden berusia 16 tahun dengan jumlah 46 responden $(75,4 \%)$, sedangkan usia rata-rata responden adalah sebesar 16 tahun. Usia seseorang hubungannya erat terhadap tingkat pengetahuan, sebab semakin bertambah usia makan akan semakin bertambah pula pengetahuan seseorang. Rosyari (2014), semakin bertambah usia seseorang maka akan semakin memahami terhadap dirinya dan mampu menerima informasi tentang berbagai hal dari berbagai macam sumber pengetahuan.

Asnita (2011) menyatakan bahwa terdapat hubungan antara variabel usia dengan pengetahuan responden mengenai HIV dan AIDS dengan $p$ value $=0,001$. Sedangkan menurut Notoadmojo (2010), pengetahuan dipengaruhi oleh beberapa 
faktor, diantaranya usia, pendidikan, sumber informasi, status ekonomi, hubungan sosial.

\section{Pengetahuan dan Sikap}

Berdasarakan Gambar 1 diketahui bahwa terdapat perbedaan nilai antara sebelum dan sesudah intervensi, artinya terdapat peningkatan pengetahuan responden tentang ODHA. Berdasarkan penelitian diketahui bahwa setelah diberikan pendidikan kesehatan dengan metode role play terjadi peningkatan pengetahuan tentang ODHA. Sebesar $88,5 \%$ responden diketahui mengalami peningkatan pengetahuan tentang ODHA. Dari 10 pertanyaan, peneliti mengambil contoh pertanyaan "terkena keringat ODHA dapat tertular HIV". Sebelum pendidikan kesehatan, sebanyak 52,5\% responden menjawab salah, artinya menganggap bahwa keringat ODHA dapat menularkan HIV. Setelah diberikan pendidikan kesehatan sebesar $100 \%$ responden atau semua responden menjawab dengan benar pertanyaan, artinya bahwa responden mengetahui keringat ODHA tidak dapat menularkan HIV. Peningkatan pengetahuan yang signifikan ini dikarenakan didalam role play terdapat pesan bahwa ada empat syarat yang harus dipenuhi supaya HIV dapat menular, yaitu Enter (adanya pintu masuk virus ke tubuh), Exit (Pintu keluar virus dari tubuh ODHA), Sufficient (jumlah virus harus cukup untuk menginfeksi), dan Survival (virus harus mampu bertahan diluar tubuh ODHA.

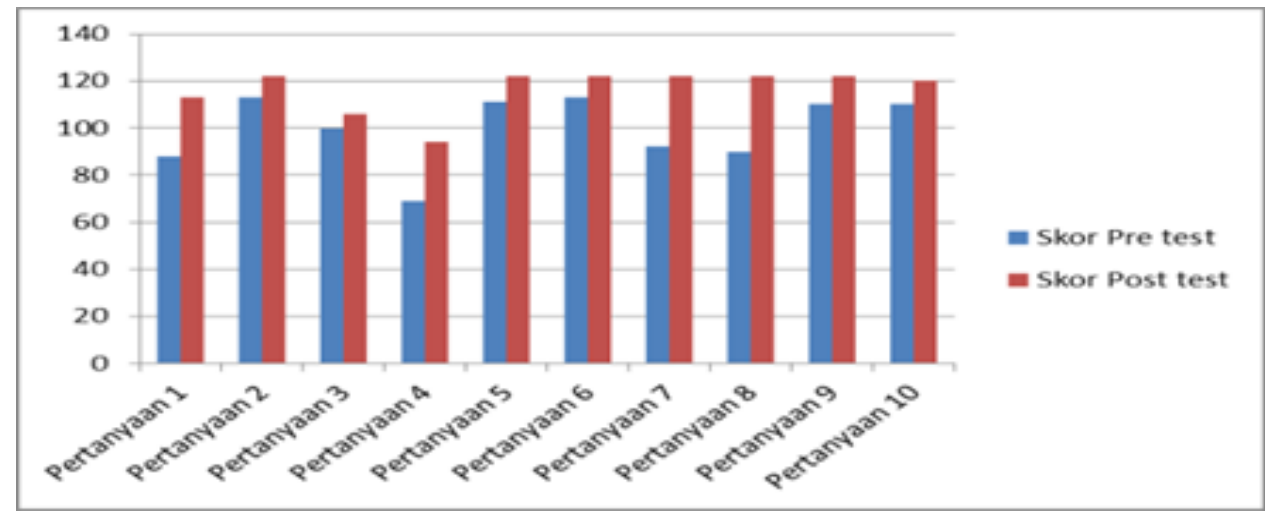

Gambar 1. Grafik nilai Pre dan Post Test Pengetahuan

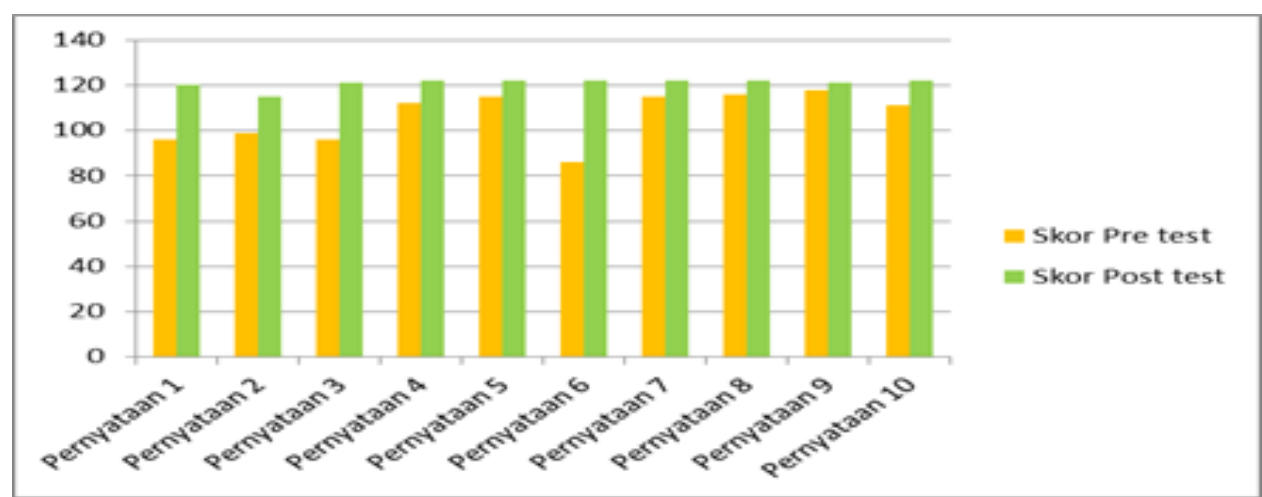

Gambar 2. Grafik nilai Pre dan Post Test Sikap 
Berdasarakan Gambar 2 diketahui bahwa terdapat perbedaan nilai antara sebelum dan sesudah intervensi, artinya pendidikan kesehatan membentuk sikap yang positif terhadap ODHA. Berdasarkan penelitian diketahui bahwa setelah diberikan pendidikan kesehatan dengan metode role play terjadi perubahan sikap yang positif terhadap ODHA yaitu sebesar $70,5 \%$ responden memiliki sikap yang positif terhadap ODHA.

Dari 10 pertanyaan, peneliti mengambil contoh terjadinya peningkatan sikap, yaitu pada pertanyaan "keluarga kita sebaiknya dijauhkan dari ODHA karena dapat tertular HIV". Sebelum pendidikan kesehatan, sebesar $59 \%$ responden masih memiliki sikap yang positif, artinya setuju bahwa keluarga responden harus dijauhkan dari ODHA karena dapat tertular HIV.

Setelah diberikan pendidikan kesehatan, sebesar $100 \%$ responden atau semua responden menjawab tidak setuju kalau keluarga harus dijauhkan dari ODHA, artinya bahwa terbentuk sikap yang positif pada semua responden, responden setuju bahwa ODHA tidak perlu dijauhi. Peningkatan pengetahuan yang signifikan ini dikarenakan ketika role play tersampaikan sebuah pesan bahwa seorang ODHA tidak boleh dijauhi, akan tetapi harus kita berikan dukungan dalam menjalani pengobatan, yang harus dijauhi adalah penyakitnya (HIV) bukan orangnya.

\section{Pengaruh Pendidikan Kesehatan terhadap Pengetahuan}

Berdasarkan hasil uji statistik diketahui bahwa nilai $p<0,05$ yaitu sebesar 0,000. Hasil ini menunjukkan bahwa terdapat pengaruh antara pendidikan kesehatan dengan menggunakan metode role play pula diketahui bahwa nilai rata-rata responden pada saat pre test sebesar 16,33 dan nilai post test responden sebesar 19,10. Hal ini menunjukkan bahwa terdapat peningkatan pengetahuan responden tentang penularan HIV setelah diberikan pendidikan kesehatan dengan metode role play.

Menurut Mubarok (2007), pengetahuan merupakan keberhasilan individu untuk menyampaikan kembali apa yang telah diketahui baik berupa jawaban yang benar dalam bentuk lisan, maupun dalam bentuk tulisan. Pengetahuan dapat pula dikatakan sebagai bagian dari terbentuknya perilaku yang baru terutama pada manusia usia dewasa.

Menurut Bloom dalam Notoadmodjo (2010) pengetahuan manusia mampu untuk menimbang dalam bersikap dan berperilaku. Pengetahuan dalam penelitian ini adalah pengetahuan responden siswa kelas X di SMAN I Sukoharjo pada saat sebelum dan setelah diberikan metode pendidikan kesehatan berupa role play. Pengetahuan mengenai cara penularan HIV dari ODHA kepada orang sehat yang dinilai dengan kuesioner sebelum dan sesudah intervensi untuk dapat diketahui pengetahuan responden dalam menjawab secara benar dari pertanyaan-pertanyaan yang ada.

Tabel 3. Pengaruh Pendidikan

Kesehatan dengan Pengetahuan

\begin{tabular}{lccc}
\hline Variabel & \multicolumn{2}{c}{ Rata-rata } & $\boldsymbol{p}-$ \\
\cline { 2 - 3 } & Pre test & Post test & value \\
\hline Pengetahuan & 16,33 & 19,10 & 0,000 \\
\hline
\end{tabular}


Hasil penelitian menunjukkan bahwa terjadi peningkatan pengetahuan responden dari skor rata-rata sebelum intervensi sebesar 16,33 meningkat menjadi 19,10 setelah intervensi. Setelah intervensi diketahui pula bahwa sebesar $88,5 \%$ responden mengalami peningkatan pengetahuan. Berdasar hasil kuesioner diketahui bahwa sebelum intervensi responden paling banyak menjawab salah pada pertanyaan "Ibu hamil yang positif HIV, bayi yang dikandungnya pasti tertular HIV". Responden yang menjawab salah sebelum intervensi sebesar 86,9 \%, akan tetapi setelah diberikan intervensi jawaban benar meningkat dari sebelumnya 13,1 \% menjadi $54,1 \%$. Peningkatan pengetahuan secara signifikan terjadi pada pertanyaan "Terkena keringat ODHA dapat tertular HIV". Sebelum intervensi, sebanyak 52,5\% responden menjawab salah, artinya menganggap bahwa keringat ODHA dapat menularkan HIV. Setelah diberikan intervensi diketahui $100 \%$ responden atau semua responden menjawab dengan benar pertanyaan, artinya bahwa responden mengetahui keringat ODHA tidak dapat menularkan

Berdasarakn hasil uji Wilcoxon diketahui bahwa p-value 0,000 hal ini berarti bahwa pendidikan kesehatan dengan metode role play memberikan pengaruh terhadap peningkatan pengetahuan responden tentang ODHA. Berdasarkan teori keterpaparan terhadap sebuah informasi (messages) yang diperoleh dari manusia (informan), media, maupun dari sebuah pendidikan kesehatan seperti role play dapat mempengaruhi peningkatan pengetahuan pada seseorang (receiver) (Sarwono, 2006). Maka intervensi pendidikan kesehatan berupa role play mampu meningkatkan pengetahuan responden. Menurut Notoadmodjo (2007) agar memperoleh hasil yang efektif dalam meningkatkan pengetahuan diperlukan alat bantu berupa media, media tidak selalu berupa benda mati, akan tetapi mahkluk hidup seperti manusia dapat pula menjadi media. Kegunaan dari media itu sendiri adalah membantu penyuluh dalam menyampaikan sebuah materi kesehatan dan supaya menarik perhatian dari responden. Pemilihan dan penggunaan media adalah komponen yang yang penting untuk dilakukan, dengan

\section{Pengaruh Pendidikan Kesehatan terhadap Sikap}

Tabel 4. Hasil uji bivariat Pendidikan

Kesehatan dengan Sikap Responden

\begin{tabular}{lrrr}
\hline Variabel & \multicolumn{2}{c}{ Rata-rata } & $\boldsymbol{p}-$ \\
\cline { 2 - 3 } & Pre test & Post test & value \\
\hline Sikap & 17,44 & 19,82 & 0,000 \\
\hline
\end{tabular}

Berdasarkan hasil uji statistik diketahui bahwa nilai $p<0,05$ yaitu sebesar 0,000. Hasil ini menunjukkan bahwa terdapat pengaruh antara pendidikan kesehatan dengan menggunakan metode role play terhadap sikap siswa tentang ODHA di SMAN I Sukoharjo. Dapat pula diketahui bahwa nilai rata-rata responden pada saat pre test sebesar 17,44 dan nilai post test responden sebesar 19,82. Hal ini menunjukkan bahwa terdapat peningkatan sikap yang positif responden tentang ODHA setelah diberikan pendidikan kesehatan dengan metode role play. Sikap adalah hasil dari sebuah proses sosialisasi yang dimana manusia akan bereaksi terhadap sebuah stimulan yang telah didapatkan. 
Proses inilah yang membedakan antara pengetahuan dan sikap, karena sikap akan memberikan aspek positif dan aspek negatif yang akan berorientasi pada persoalan yang bersifat umum, sedangkan menurut Nurdjaya (2005) sikap merupakan rasa setuju dan tidak setuju terhadap sesuatu. Menurut Fishbein dan Ajzen dalam Notoadmojo (2010), sikap merupakan faktor predisposi (latar belakang) yang dipelajri untuk memberikan respon positif atau negatif terhadap sebuah objek ataupun situasi. Sikap dalam penelitian ini adalah tanggapan atau respon responden siswa kelas X di SMAN I Sukoharjo pada saat sebelum dan setelah diberikan metode role play. sikap responden dalam merespon setiap pernyataanpernyataan yang ada dalam kuesioner.

\section{Berdasarkan penelitian}

diketahui bahwa bahwa terjadi peningkatan sikap responden dari skor rata-rata sebelum intervensi sebesar 17,44 meningkat menjadi 19,82 setelah intervensi. Setelah intervensi diketahui pula bahwa sebesar 70,5\% responden mengalami peningkatan sikap, dari yang sebelumnya tidak setuju (menolak) menjadi setuju (menerima). Berdasar hasil kuesioner diketahui bahwa sebelum intervensi responden paling banyak menjawab tidak setuju pada pernyataan "Keluarga kita sebaiknya dijauhkan dari ODHA karena dapat tertular HIV". Responden yang menjawab setuju sebelum intervensi sebesar 59\%, akan tetapi setelah diberikan intervensi terjadi peningkatan sikap sebesar $41 \%$, yang artinya 18 siswa menyatakan setuju untuk menjauhi ODHA, berubah sikapnya menjadi tidak setuju untuk menjahuhi ODHA. Hal ini berarti semua responden memberikan respon positif bahwa tidak perlu menjauhi ODHA karena proses penularan HIV tidak mudah. Sikap positif responden selalu terjaga pada pernyataan "HIV adalah penyakit yang disebabkan kutukan atau azab dari tuhan Yang Maha Esa". Sebesar 93,4\% responden memiliki sikap yang positif sebelum intervensi, dan setelah intervensi sikap ini meningkat menjadi 98,4\%. Hal ini berarti bahwa hampir semua responden meyakini bahwa HIV bukanlah penyakit yang disebabkan oleh kutukan atau azab dari tuhan.

Berdasarakn hasil uji statistik diketahui bahwa p-value 0,000 hal ini berarti bahwa pendidikan kesehatan dengan metode role play memberikan pengaruh terhadap terbentuknya sikap yang positif responden tentang ODHA. Menurut Sarwono (2006), sikap merupakan siapnya manusia dalam bertindak terhadap suatu hal. Sikap mampu bersifat positif dan atau bersifat negatif. Sikap yang positif, akan cenderung melakukan tindakan berupa menyayangi, mengharapakan, menyenangi, dan mendekati objek tertentu. Sedangkan sikap yang negatif akan cenderung melakukan tindakan membenci, menjauhi, menghindari, dan tidak menyukai suatu obyek tertentu. Sedangkan menurut Purwanto (2003) sikap merupakan bentuk reaksi terhadap sebuah stimulus. Sebuah kecenderungan melakukan reaksi dengan langka-langkah tertentu terhadap sebuah stimulus dan atau situasi yang telah dihadapi. Sikap terapat beberapa tingkatan diantaranya menerima (receiving), merespon (responding), menghargai (valuing), dan bertanggung jawab (responsible). Menurut Machfoedz (2008) sikap memiliki tiga komponen, yaitu: (1) kognitif, (2) afektif, dan (3). perilaku. 
Hal ini sejalan dengan pendapat Kholid (2012) bahwa sikap memiliki tiga komponen, yaitu: (1). komponen kognitif, (2) perasaan, (3) kecenderungan bertindak (action tendency).

\section{KESIMPULAN}

Pendidikan kesehatan dengan metode role play memberikan pengaruh terhadap peningkatan pengetahuan dan sikap tentang ODHA siswa kelas X di SMAN I Sukoharjo

\section{UCAPAN TERIMA KASIH}

Ucapan terima kasih
disampaikan kepada Ketua LPPM
UNIVET Bantara Sukoharjo yang telah
memberikan dukungan pendanaan
dalam pelaksanaan penelitian ini.
Peneliti juga mengucapkan terima
kasih yang sebesar-besarnya kepada
Kepala Sekolah SMA N I Sukoharjo
yang telah berkenan bekerjasama
dalam pelaksanaan dan kelancaran
penelitian ini.

\section{DAFTAR PUSTAKA}

Asnita. (2011). Hubungan Faktor Sosiodemografi Dengan Pengetahuan Dan Sikap Tenaga Kerja Indonesia Tentang HIV/AIDS. Skripsi. Universitas Indonesia. Depok

Card, J. J., Amarillas, A., Conner, A., Akers, D. D., Solomon, J., \& DiClemente, R. J. (2008). The Complete HIV and AIDS Teaching Kit. New York: Springer Publishing Company

Hati Konstantinus, Zahroh Shaluhiyah, Antono Suryo. (2017). Stigma Masyarakat Terhadap ODHA di Kota Kupang Provinsi NTT. Jurnal Promosi Kesehatan Indonesia, 12 (1): 62-77

Kementerian Kesehatan. (2011). Pedoman Penghapusan Stigma dan Diskriminasi Bagi Pengelola Program, Petugas Layanan Kesehatan dan Kader. Jakarta: Balitbangkes

Kemkes RI, (2018). Laporan Nasional Riset Kesehatan Dasar 2018. Jakarta Balitbankes

Kholid, A. (2012). Promosi Kesehatan dengan pendekatan teori prilaku, media, dan aplikasinya. Perpustakaan Nasional: Katalog Dalam Terbitan (KDT). Jakarta: Rajawali Pers

KPA Kabupaten Sukoharjo. (2018). Laporan Perkembangan HIV dan AIDS Kabupaten Sukoharjo Tahun 2018. Sukoharjo: KPA Kabupaten Sukoharjo

KPA. (2009). ODHA dan Akses Pelayanan Kesehatan Dasar Penelitian Partisipatif. WHO. Jakarta: UNAIDS

Machfoedz, I, Suryani, E, Sutrisno, Santoso, S. (2008). Pendidikan Kesehatan Bagian Dari Promosi Kesehatan.Yogyakarta: Fitramaya

Mubarak. (2007). Promosi Kesehatan Sebuah Pengamatan Proses Belajar Mengajar dalam Pendidikan. Yogyakarta: Graha Ilmu

Notoatmodjo, S. (2007). Promosi Kesehatan dan Ilmu Perilaku. Jakarta: Penerbit Rineka Cipta. 
Notoatmodjo, S. (2010). Promosi Kesehatan dan Aplikasinya. Jakarta: Rineka Cipta

Nurdjaya, I.G. (2005). Sikap dan Motivasi Pembelajaran Bahasa, Jurnal Pendidikan dan Pengajaran IKIPN Singaraja, 38 (3): 50-64.

Purwanto, N. (2003). Psikologi Pendidikan, Bandung: PT Remaja Rosdakarya

Purwanto. (2008). Evaluasi Hasil Belajar. Yogyakarta: Pustaka Pelajar.

Rosyari, F.N.A. (2014). Perbedaan Pengaruh Intervensi Penyuluhan Antara Media Kartu Berjodoh Dengan Media Lembar Balik Terhadap Peningkatan Pengetahuan Gizi Dan Faktor Yang Berhubungan Pada Ibu Balita Di Kecamatan Babelan, Kabupaten Bekasi. Skripsi. Universitas Islam Negeri Syarif Hidayatullah Jakarta.

Sardiman A.M. (2011). Interaksi \& Motivasi Belajar Mengajar. Jakarta: PT. Raja Grafindo Persada.

Sarwono, S.W. 2006. Pengantar Umum Psikologi, Jakarja: PT Bulan Bintang. 